\title{
PELATIHAN PENERAPAN MODEL PEMBELAJARAN PENEMUAN TERBIMBING UNTUK MENEMUKAN LUAS BANGUN DATAR BAGI GURU SD DI KKG GUGUS I KECAMATAN SIRENJA KABUPATEN DONGGALA
}

\author{
Gandung Sugita $^{1)}$, Anggraini ${ }^{2)}$, Sutji Rochaminah ${ }^{3)}$, Maxinus Jaeng ${ }^{4)}$ \\ gandungpplw@gmail.com ${ }^{l)}$,anggiplw67@gmail.com ${ }^{2}$, sucipalu@gmail.com ${ }^{3)}$, maxjaeng@yahoo.com ${ }^{4}$
}

\begin{abstract}
Abstrak: Pelatihan yang dilakukan dalam kegiatan pengabdian kepada masyarakat ini adalah penerapan salah satu model dalam pembelajaran matematika, yaitu model pembelajaran penemuan terbimbing. Model ini diwajibkan dalam Kurikulum 2013. Melalui model ini diharapkan siswa menemukan sendiri konsep-konsep matematika khususnya luas bangun datar, sehingga ilmu tersebut tidak hanya dihafal tapi di pahami dengan baik. Oleh karena itu, tim pengabdian melakukan kegiatan ini dengan tujuan untuk membantu guru-guru SD di KKG Gugus I kecamatan Sirenja kabupaten Donggala dalam penerapan model pembelajaran penemuan terbimbing sesuai amanat Kurikulum 2013. Model pembelajaran penemuan terbimbing yang disimulasikan oleh tim Pengabdian, yaitu menemukan luas bangun datar yang meliputi: persegi, persegi panjang, segitiga, jajargenjang, belahketupat, trapesium dan lingkaran. Penerapan model ini menggunakan karton sebagai alat peraga, yang dapat dibentuk menjadi bangun datar. Berdasarkan hasil angket, diperoleh: 45,83\% guru menyatakan sangat setuju bahwa materi tentang Model Pembelajaran Penemuan Terbimbing yang disampaikan, memberikan pemahaman yang baik tentang langkah-langkah pembelajaran penemuan terbimbing, dan 54,17\% guru menyatakan setuju. Selain itu, 54,17\% guru menyatakan sangat setuju bahwa Penerapan Model Pembelajaran PenemuanTerbimbing pada materi menemukan luas bangun datar yang disimulasikan, dapat menumbuhkan motivasi dan keaktifan siswa dalam pembelajaran, serta menciptakan pembelajaran yang tidak hanya menghafal rumus luas tetapi mampu menemukan rumus tersebut, dan 45,83\% guru menyatakan setuju.
\end{abstract}

Kata Kunci: Model Pembelajaran Penemuan Terbimbing, Luas Bangun Datar

Permendikbud No. 65 Tahun 2013 tentang Standar Proses Pendidikan Dasar dan Menengah telah mengisyaratkan tentang perlunya proses pembelajaran yang dipandu dengan kaidah-kaidah pendekatan saintifik/ilmiah. Upaya penerapan Pendekatan saintifik/ilmiah dalam proses pembelajaran ini sering disebut-sebut sebagai ciri khas dan menjadi kekuatan tersendiri dari keberadaan Kurikulum 2013(K 13), yang tentunya menarik untuk dipelajari dan dielaborasi lebih lanjut.

Guru sebagai satu diantara unsur-unsur dalam proses belajar mengajar, memiliki pengaruh yang cukup besar terhadap kegiatan belajar mengajar, khususnya mengajarkan matematika. Oleh karena itu guru harus mampu menciptakan situasi yang dapat menunjang perkembangan belajar peserta didik. Semua ini tidak terlepas bagaimana guru mampu mengelola pembelajaran dengan menerapkan model pembelajaran yang sesuai dengan materi yang diajarkan, dan cocok dengan kaidah K 13. Model pembelajaran penemuan terbimbing merupakan suatu model yang sejalan dengan pendekatan saintifik.

Model pembelajaran penemuan terbimbing memberi kesempatan kepada peserta didik untuk memperoleh pengetahuan dengan belajar menemukan. Belajar penemuan menunjukkan beberapa kebaikan diantaranya, yaitu: pengetahuan itu bertahan lama, hasil belajar penemuan mempunyai efek transfer yang lebih baik, secara menyeluruh belajar penemuan meningkatkan penalaran peserta didik. Sementara itu peran teman dalam proses belajar 
penemuan (discovery learning) cukup diperlukan, mereka bisa saling bertukar informasi dari apa yang mereka pelajari dan temukan sendiri. Selain itu model ini bisa dilaksanakan dalam bentuk diskusi kelas, demonstrasi, atau kegiatan laboratorium (Ahmadi dalam Bupulenam, 2011).

Model pembelajaran penemuan terbimbing cocok diterapkan pada materi geometri untuk menemukan rumus-rumus. Hasil penelitian Khaeri (2014) menemukan bahwa siswa kesulitan pada geometri, khususnya pada materi luas permukaan dan volume kubus dan balok disebabkan karena siswa mengalami kesulitan dalam membedakan rumus luas permukaan dan volume kubus maupun balok, hal ini terjadi karena siswa cenderung hanya menghafal rumus. Sejalan dengan hasil penelitian Anita (2017) yang menyatakan bahwa siswa sering kali mengalami kesulitan pada pembelajaran matematika yang berkaitan erat dengan geometri khususnya materi luas permukaan kubus, volume kubus, luas permukaan balok dan volume balok. Pada materi ini, siswa mudah lupa dan keliru dengan penggunaan rumus.

Berdasarkan permasalahan yang dihadapi siswa pada materi Geometri di SD, maka tim pengabdian melakukan diskusi dengan guru SD di KKG Gugus I kecamatan Sirenja kabupaten Donggala pada kegiatan pengabdian tanggal 2 Oktober 2019. Dari hasil diskusi diperoleh informasi bahwa guru-guru belum pernah memberikan kesempatan siswa untuk menemukan rumus-rumus luas bangun datar, mereka hanya menuliskan rumus dan melatih siswa untuk menggunakan rumus.

Guru SD di KKG Gugus I Kecamatan Sirenja Kabupaten Donggala sangat mengharapkan adanya penyuluhan atau pelatihan untuk mengatasi kesulitan siswa terkait dengan materi geometri. Oleh karena itu, dilaksanakan pelatihan penerapan model penemuan terbimbing pada pembelajaran menemukan rumus luas bangun datar.

Tujuan dari pengabdian ini adalah membantu guru-guru SD di KKG Gugus I kecamatan Sirenja kabupaten Donggala dalam menerapkan model pembelajaran penemuan terbimbing untuk menemukan luas bangun datar. Target dan luaran yang ingin dicapai pada kegiatan pengabdian ini adalah guru SD di KKG Gugus I Kecamatan Sirenja Kabupaten Donggala memiliki kompetensi yang memadai dalam memahami model pembelajaran penemuan terbimbing, dan mampu mengaktifkan siswa untuk menemukan sendiri luas bangun datar. Bangun datar yang ditemukan luasnya yaitu: persegi, persegipanjang, segitiga, jajargenjang, belahketupat, trapesium dan lingkaran. Selain itu, hasil pengabdian akan dipublikasikan pada Jurnal Pendidikan Matematika FKIP Universitas Tadulako

\section{METODE PELAKSANAAAN}

Kegiatan ini dilaksanakan selama 2 hari yang terdiri dari 1 hari observasi awal dan 1 hari untuk pelatihan penerapan model pembelajaran penemuan terbimbing untuk menemukan luas bangun datar. Lokasi kegiatan pengabdian dilaksanakan di SDN 25 Sirenja, Kecamatan Sirenja Kabupaten Donggala. Sasaran dari pengabdian adalah Guru SD di KKG Gugus I Kecamatan Sirenja Kabupaten Donggala. Pelaksanaan kegiatan pengabdian bagi guru dapat dilihat dalam tabel di bawah ini:

Tabel 1. Kegiatan Pengabdian bagi Guru

\begin{tabular}{ccll}
\hline No & Uraian Kegiatan & \multicolumn{1}{c}{ Tujuan } & Sasaran \\
\hline 1 Wawancara & $\begin{array}{l}\text { Mendapatkan informasi dan data-data tentang } \\
\text { kegiatan layanan informasi }\end{array}$ & Guru \\
2 Survey Lapangan & $\begin{array}{l}\text { Untuk melihat sekaligus mengamati kondisi } \\
\text { real di lapangan disesuaikan dengan program yang }\end{array}$ & Guru \\
\hline
\end{tabular}


Gandung Sugita, Anggraini, Sutji Rochaminah, dan Maxinus Jaeng, Pelatihan...57 akan dilaksanakan

3 Diskusi dengan Untuk memperoleh informasi tentang penerapan Guru guru

4 Kegiatan Edukatif dan Pelatihan model pembelajaran matematika Untuk Meningkatkan penguasaan guru dalam Guru menerapkan model pembelajaran penemuan terbimbing

5 Evaluasi Untuk Mengetahui sekaligus mengukur sampai Guru dimana letak berhasilnya kegiatan program pelatihan

Adapun kegiatan pengabdian ini dilakukan oleh Tim Pengabdian yang beranggotakan 4 orang dosen Program Studi Pendididkan Matematika FKIP Universitas Tadulako dan melibatkan 2 orang mahasiswa dengan deskripsi tugas pada Tabel 2.

Tabel 2 Tugas Personalia Pengabdian

\begin{tabular}{|c|c|c|c|}
\hline No & $\begin{array}{c}\text { Nama } \\
\text { Pengabdi }\end{array}$ & Jabatan & Tugas \\
\hline 1 & $\begin{array}{l}\text { Gandung } \\
\text { Sugita }\end{array}$ & Ketua & $\begin{array}{l}\text { 1. Merancang proposal kegiatan pengabdian kepada } \\
\text { masyarakat. } \\
\text { 2. Menyusun materi untuk kegiatan pengabdian } \\
\text { 3. Pemateri dalam kegiatan pelatihan } \\
\text { 4. Menyediakan segala bahan, alat dan sarana } \\
\text { pendukung pelaksanaan pengabdian } \\
\text { 5. Menyusun Laporan Akhir kegiatan pengabdian }\end{array}$ \\
\hline 2 & Anggraini & Anggota & $\begin{array}{l}\text { 1. Merancang proposal kegiatan pengabdian kepada } \\
\text { masyarakat } \\
\text { 2. Menyediakan segala bahan, alat dan sarana } \\
\text { pendukung pelaksanaan pengabdian. } \\
\text { 3. Membantu simulasi model penemuan terbimbing } \\
\text { 4. Membantu menyusun laporan akhir kegiatan } \\
\text { pengabdian }\end{array}$ \\
\hline 3 & $\begin{array}{l}\text { Sutji } \\
\text { Rohaminah }\end{array}$ & Ang & $\begin{array}{l}\text { 1. Merancang proposal kegiatan pengabdian kepada } \\
\text { masyarakat } \\
\text { 2. Membantu menyediakan segala bahan, alat dan } \\
\text { sarana pendukung pelaksanaan pengabdian. } \\
\text { 3. Membantu simulasi model penemuan terbimbing } \\
\text { 4. Membantu menyusun laporan akhir kegiatan } \\
\text { pengabdian. }\end{array}$ \\
\hline 4 & $\begin{array}{l}\text { Maxinus } \\
\text { Jaeng }\end{array}$ & Anggota & $\begin{array}{l}\text { 1. Merancang proposal kegiatan pengabdian kepada } \\
\text { masyarakat } \\
\text { 2. Membantu menyediakan segala bahan, alat dan } \\
\text { sarana pendukung pelaksanaan pengabdian. } \\
\text { 3. Membantu simulasi model penemuan terbimbing } \\
\text { 4. Membantu menyusun laporan akhir kegiatan } \\
\text { pengabdian. }\end{array}$ \\
\hline 5 & Irawati & Anggota & $\begin{array}{l}\text { 1. Membantu menyediakan segala bahan, alat dan } \\
\text { sarana pendukung pelaksanaan pengabdian. } \\
\text { 2. Menggandakan dan mengadministrasikan laporan } \\
\text { akhir kegiatan pengabdian }\end{array}$ \\
\hline
\end{tabular}


6 Andi Ulfa Anggota 1. Membantu menyediakan segala bahan, alat dan sarana pendukung pelaksanaan pengabdian.

2. Menggandakan dan mengadministrasikan laporan akhir kegiatan pengabdian

\section{HASIL PENGABDIAN}

Kegiatan pengabdian dilaksanakan pada hari Sabtu, 5 September 2020. Kegiatan ini berjalan dengan lancar dan efektif. Guru-guru sangat senang mengikuti kegiatan ini, karena mereka langsung mencoba menerapkan model pembelajaran Penemuan Terbimbing, dengan menggunakan alat peraga untuk menemukan luas daerah bangun datar yang telah dibuat oleh tim pengabdi. Alat peraga terbuat dari karton dan dapat digunting-gunting untuk memperoleh luas bangun datar yang diinginkan. Alat peraga tersebut dapat menumbuhkan kreativitas Guru/siswa untuk membentuk bangun datar dengan cara yang berbeda-beda, sehingga dapat ditemukan luasnya dengan mudah.

Hasil dari pengamatan tim pengabdi selama kegiatan, guru masih memerlukan waktu yang lama untuk menggnting dan membentuk bangun datar yang akan ditemukan luasnya. Hal ini sesuai dengan kelemahan dari model pembelajaran Penemuan Terbimbing yaitu membutuhkan waktuyang lama dalam penerapannya. Berdasarkan beberapa pertanyaan yang diajukan tim pengabdi.

Untuk mendapat gambaran tentang tanggapan para peserta pelatihan penerapan model penemuan terbimbing untuk menemukan luas daerah bangun datar, maka kepada semua peserta pelatihan diberikan angket. Angket ini berisi empat pertanyaan yang terkait dengan keberhasilan kegiatan pengabdian yang dilakukan oleh Tim Pengabdi Program Studi Pendididkan Matematika Fakultas Keguruan dan Ilmu Pendidikan Universitas Tadulako. Hasil angket respon dari semua peserta pelatihan disajikan pada tabel berikut.

Tabel 3 Respon Peserta Terhadap Kegiatan Pelatihan

\begin{tabular}{|c|c|c|c|c|c|}
\hline \multirow{2}{*}{ No } & \multirow{2}{*}{ Pertanyaan } & \multicolumn{4}{|c|}{ Alternatf Jawaban } \\
\hline & & SS & $S$ & TS & STS \\
\hline 1. & $\begin{array}{l}\text { Materi tentang Model Pembelajaran Penemuan } \\
\text { Terbimbing yang disampaikan, memberikan } \\
\text { pemahaman yang baik tentang langkah-langkah } \\
\text { pembelajaran penemuan terbimbing }\end{array}$ & $90,48 \%$ & $9,52 \%$ & & \\
\hline 2. & $\begin{array}{l}\text { Pelatihan penerapan Model Pembelajaran Penemuan } \\
\text { Terbimbing pada materi menemukan luas bangun datar } \\
\text { yang dilakukan, memberikan pemahaman yang baik } \\
\text { tentang konsep bangun datar }\end{array}$ & $57,14 \%$ & $42,86 \%$ & & \\
\hline 3. & $\begin{array}{l}\text { Pelatihan penerapan Model Pembelajaran Penemuan } \\
\text { Terbimbing yang dilakukan, memberikan pemahaman } \\
\text { yang baik tentang cara mengajarkan luas bangun datar }\end{array}$ & $76,19 \%$ & $23,81 \%$ & & \\
\hline 4. & $\begin{array}{l}\text { Penerapan Model Pembelajaran Penemuan Terbimbing } \\
\text { pada materi menemukan luas bangun datar yang } \\
\text { disimulasikan, dapat menumbuhkan motivasi dan } \\
\text { keaktifan siswa dalam pembelajaran, serta menciptakan } \\
\text { pembelajaran yang tidak hanya menghafal rumus luas } \\
\text { tetapi mampu menemukan rumus tersebut }\end{array}$ & $66,67 \%$ & $33,33 \%$ & & \\
\hline
\end{tabular}


Gandung Sugita, Anggraini, Sutji Rochaminah, dan Maxinus Jaeng, Pelatihan...59 Keterangan: SS = Sangat Setuju, S = Setuju, TS = Tidak Setuju, STS = Sangat Tidak Setuju

Berdasarkan tanya jawab dan pengamatan selama kegiatan berlangsung, kegiatan pengabdian pada masyarakat ini memberikan hasil sebagai berikut:

1. Meningkatnya pemahaman guru SD di KKG Gugus 1 Kecamatan Sirenja Kabupaten Donggala pada konsep luas bangun datar.

2. Meningkatnya keterampilan guru SD di KKG Gugus 1 Kecamatan Sirenja Kabupaten Donggala dalam menggunakan model pembelajaran penemuan terbimbing untuk menemukan luas daerah bangun datar.

Kegiatan pelatihan penerapan model pembelajaran penemuan terbimbing untuk menemukan luas daerah bangun datar mendapat sambutan yang sangat antusias dari guru-guru SD di KKG Gugus 1 kecamatan Sirenja kabupaten Donggala. Antusias ini terlihat sebelum kegiatan pelatihan dilakukan. Hal ini terindikasi dari adanya keinginan yang kuat dari guruguru untuk mengikuti kegiatan pelatihan. Antusias guru juga terlihat pada setiap tahap pelaksanaan kegiatan pelatihan. Mereka nampak sangat serius memperhatikan, menyimak, mengajukan pertanyaan terkait dengan kegiatan pelatihan.

Selain antusias yang tinggi, peserta pelatihan juga sangat aktif selama kegiatan pelatihan. Mereka tidak sekedar datang, duduk, mendengar dan mencatat apa yang disampaikan oleh tim pengabdi, tetapi mereka aktif bertanya tentang materi yang diberikan. Mereka aktif menyimak dan memperhatikan secara seksama serta terlibat langsung dalam simuasi yang dilakukan tim pengabdi

Kegiatan pelatihan ini dirasakan sangat bermanfaat oleh guru-guru di KKG Gugus 1 kecamatan Sirenja kabupaten Donggala, sebab mereka telah mendapatkan gambaran yang cukup jelas tentang penerapan model pembelajaran penemuan terbimbing untuk menemukan luas daerah bangun datar dan mencaba langsung mengutak-atik alat peraga untuk menemukan luas daerah bangun datar.

\section{SIMPULAN}

Dari kegiatan pengabdian pada masyarakat ini dapat disimpulkan bahwa adanya peningkatan pemahaman guru SD di KKG Gugus 1 Kecamatan Sirenja Kabupaten Donggala tentang penerapan model pembelajaran penemuan terbimbing untuk menemukan luas daerah bangun datar dan meningkatnya keterampilan guru SD di KKG Gugus 1 Kecamatan Sirenja Kabupaten Donggala dalam menggunakan alat peraga untuk menemukan luas daerah bangun datar pada penerapan model pembelajaran penemuan terbimbing.

\section{SARAN}

Mengingat besarnya manfaat kegiatan pengabdian pada masyarakat, maka selanjutnya perlu mengadakan pelatihan serupa pada guru SD di sekolah lainnya dan monitoring pada guru yang telah mengikuti pelatihan saat menerapan model pembelajaran penemuan terbimbing untuk menemukan luas daerah bangun datar

\section{DAFTAR PUSTAKA}

Anita. (2017). Penerapan Metode Penemuan terbimbing Untuk Meningkatkan Hasil Belajar Siswa Pada Materi Luas Permukaan Dan Volume Bangun Ruang Di Kelas VIII SMP Negeri 4 Sigi. Jurnal Elektronik Pendidikan Matematika Tadulako, Volume 
04 Nomor 04. [Online]. Tersedia: http://jurnal.untad.ac.id/jurnal/index. php/JEPMT/ article/vie / 8455. [20 Desember 2019].

Bupulenam, B. (2011). Belajar Penemuan Menurut Jerome Bruner. [Online]. Tersedia:http://bupulenambudi.blogspot.com/2011/08/belajar-penemuan -menurutjerome-bruner.html. [25 Maret 2019].

Khaeri, F. (2014). Penerapan Model Pembelajaran Reciprocal Teaching untuk Meningkatkan Hasil Belajar Siswa pada Materi Luas Permukaan dan Volume Kubus dan Balok di Kelas VIII SMP Negeri 16 Palu. Jurnal Elektronik Pendidikan Matematika Tadulako, Volume 02 Nomor 03. [Online]. Tersedia: http://jurnal.untad.ac.id/jurnal/index.php/JEPMT/ article/view/8306/6589. [29 Maret 2019].

Markaban. (2006). Model Pembelajaran Matematika dengan Pendekatan Penemuan Terbimbing, [Online]. Tersedia: http://p4tkmatematika.org/ downloads/ppp/PPP Penemuan Terbimbing. pdf. [25 Maret 2019]. 